\title{
MORFOLOGI DAN MUTU FISIK BENIH KENANGA (Cananga odorata (Lam.) Hook.f. \& Thomson forma genuina)
}

\author{
Morphology and Physical Quality of Cananga Seeds (Cananga odorata (Lam.) Hook.f. \& \\ Thomson forma genuina)
}

\author{
Arum Sekar Wulandari ${ }^{1 *}$ dan Ferawati Oktia Nurhayani ${ }^{1}$
}

(Diterima Februari 2019/ Disetujui Agustus 2019)

\begin{abstract}
Cananga is one of the forestry plant that has high economic value and benefits. The provision of high-quality seed is necessary for establishy cananga plantation. The aim of this study was to observe the fruit morphology and analyze the physical quality of cananga seeds. This research method consisted of (1) morphological observation of seed (fruit size, number of seeds per fruit, and their correlation); (2) physical quality testing of seed (the weight of 1000 seeds and seed moisture content). The observations showed that the fruit length were 7.40-27.5 mm, width 0.43-16.63 mm and weight 0.36-2.88 grams. The size of fruit have significant effect on the number of seeds in the fruit, there are 1-12 seeds in one cananga fruit. There are approximately 16000 seeds in $1 \mathrm{~kg}$ of cananga seed. Seed moisture content of fruit that taken from tree (51.20-59.20\%) is higher than seed water content of fruits that fall due to ripe physiologically (34.57-37.82\%).
\end{abstract}

Key words: cananga, morphological, physical quality, seed

\section{PENDAHULUAN}

Kenanga (Cananga odorata (Lam.) Hook.f. \& Thomson) merupakan salah satu tanaman kehutanan yang tumbuh dengan baik di daerah tropis dataran rendah yang lembab. Di Indonesia ada dua forma $C$. odorata yaitu $C$. odorata forma macrophylla yang dikenal dengan kenanga jawa dan $C$. odorata forma genuina yang dikenal dengan kenanga ylang-ylang. Dalam penelitian ini yang digunakan adalah $C$. odorata forma genuina. Jenis ini dapat tumbuh pada ketinggian 0-1800 m, suhu 20-27 ${ }^{\circ} \mathrm{C}$ dan rata-rata curah hujan tahunan 650-4000 mm. Kenanga dapat tumbuh pada tanah lempung berpasir dan tanah vulkanik yang subur dengan $\mathrm{pH}$ 4.5-8. Kenanga memiliki tinggi yang dapat mencapai $40 \mathrm{~m}$ dan diameter batang yang lurus sekitar $45 \mathrm{~cm}$. Kulit batangnya halus dan berwarna abu-abu pucat hingga keperakan. Daun berwarna hijau yang tersusun secara alternate, pinggiran daun bergelombang dan vena lateral berwarna keputih-putihan pada kedua sisinya. Tangkai daun berbentuk ramping dengan panjang 1-2 cm (Orwa et al. 2009).

Kenanga memiliki berbagai manfaat dan keunggulan. Kayu kenanga sering dimanfaatkan sebagai bahan bakar, konstruksi lokal, maupun pembuatan korek api. Kulit kayu kenanga sering digunakan untuk membuat tali. Biji yang dihasilkan dapat digunakan untuk mengobati demam (Orwa et al. 2009). Masyarakat banyak menggunakan bunga kenanga

\footnotetext{
${ }^{1}$ Departemen Silvikultur, Fakultas Kehutanan, IPB University

Kampus Darmaga, Bogor 16680

* penulis korespondensi:

E-mail: rr_arum@yahoo.com
}

sebagai bahan ritual budidaya dan diekstraksi untuk diambil minyak atsirinya (Propantoko 2018). Selain itu, bunganya dapat digunakan untuk menghindari gigitan nyamuk malaria dan daunnya digosokkan pada kulit untuk mengobati gatal. Minyak yang dihasilkan memiliki efek seperti obat penenang pada sistem syaraf dan membantu mengatasi kecemasan, ketegangan atau ketakutan (Orwa et al. 2009); antidepresan dan obat penenang bagi manusia (Zhang et al. 2016).

Kenanga memiliki banyak manfaat, sehingga budidaya kenanga sangat diperlukan untuk mendukung keberadaannya di alam. Perbanyakan kenanga biasanya menggunakan benih. Benih merupakan salah satu faktor pendukung budidaya kenanga secara generatif. Penyediaan benih bermutu baik dan dalam jumlah yang banyak sangat diperlukan, sehingga dapat dihasilkan bibit yang bermutu tinggi sesuai jumlah yang diinginkan. Saat ini informasi terkait morfologi buah dan mutu fisik benih kenanga masih terbatas. Pemahaman tentang struktur morfologi buah dan mutu fisik benih kenanga sangat penting dalam upaya penyediaan benih bermutu tinggi.

Pengujian mutu benih bertujuan mengetahui kualitas dari suatu benih (Sutopo 2002). Pengujian mutu benih terdiri atas mutu fisik, mutu fisiologis dan mutu genetis. Pengujian mutu fisik benih merupakan pengujian yang dilakukan pada lot benih yang telah disimpan. Uji mutu fisik benih meliputi uji berat 1000 butir benih, uji kadar air benih, dan uji kemurnian benih. Namun, ruang lingkup penelitian yang dilakukan terhadap mutu fisik benih kenanga meliputi berat 1000 butir benih dan penetapan kadar air awal benih. Tujuan penelitian ini untuk mendeskripsikan morfologi buah dan menganalisis mutu fisik benih kenanga. 


\section{METODE PENELITIAN}

\section{Alat dan Bahan}

Bahan yang digunakan dalam penelitian ini ialah buah dan benih kenanga. Alat yang digunakan dalam penelitian ini adalah timbangan digital ( $g$ ) dengan ketelitian 0.01, jangka sorong, oven, cawan krusibel, dan gunting kuku.

\section{Prosedur Penelitian}

\section{Morfologi buah kenanga}

Pengunduhan buah. Buah diunduh dari satu pohon kenanga yang berada di halaman Asrama Putri, Institut Pertanian Bogor (koordinat: 6 33'23.0"S $\left.106^{\circ} 43^{\prime} 55.0^{\prime \prime} \mathrm{E}\right)$. Pengunduhan dilakukan dengan cara (1) memetik buah yang sudah masak dari pohon dengan menggunakan galah; (2) mengambil buah yang sudah jatuh di tanah. Buah yang dipilih adalah buah yang masih utuh, tidak busuk, dan berwarna hijau tua atau ungu kehitaman.

Pengukuran buah dan ekstraksi benih. Buah kenanga (100 buah) hasil pengunduhan ditimbang beratnya kemudian diukur panjang dan lebarnya. Buah selanjutnya diekstraksi dengan cara kering yaitu mengeluarkan benih dari buah dan dihitung jumlah benih pada masing-masing buah. Selanjutnya, untuk mengetahui tipe perkecambahan dari benih kenanga dilakukan pengecambahan benih sebanyak 50 butir benih. Pengamatan tipe perkecambahan dilakukan sampai benih kenanga berkecambah (1 bulan).

\section{Pengujian mutu fisik benih kenanga}

Penentuan berat 1000 benih. Penentuan berat bertujuan untuk menghitung berat 1000 butir benih bertujuan untuk memperkirakan jumlah benih per $\mathrm{kg}$. Menurut Peraturan Direktur Jenderal Rehabilitasi Lahan dan Perhutanan Sosial Nomor: P.06/V-SET/2009 berat 1000 butir benih dapat ditentukan dengan rumus sebagai berikut:

$$
S^{2}=\frac{n\left(\sum x^{2}\right)-\left(\sum x\right)^{2}}{n(n-1)}
$$

Keterangan: $s^{2}=$ ragam

$$
\begin{aligned}
\mathrm{x}= & \text { berat tiap ulangan dalam gram } \\
& (100 \text { benih) } \\
\mathrm{n}= & \text { jumlah ulangan }(8) \\
\Sigma= & \text { jumlah }
\end{aligned}
$$

Koefisien keragaman dapat ditentukan dengan rumus sebagai berikut:

$$
C V=\frac{s}{x} x 100 \%
$$

Keterangan: $\mathrm{CV}=$ koefisien keragaman

$\mathrm{X}=$ rata-rata berat 100 benih

$\mathrm{s}=\operatorname{standar}$ deviasi $\left(\sqrt{s^{2}}\right.$
Jumlah benih per $\mathrm{kg}$ dapat ditentukan dengan rumus sebagai berikut:

$$
\text { Jumlah benih per } \mathrm{kg}=\frac{1000}{\text { Berat } 1000 \text { benih }} \times 1000
$$

Penentuan kadar air benih. Benih kenanga yang telah diekstraksi kemudian digunakan untuk mengukur kadar air benih. Menurut Sudrajat et al. (2015), kadar air awal benih diukur dengan menggunakan oven pada suhu $101-105{ }^{\circ} \mathrm{C}$ selama $17 \pm 1$ jam. Benih yang digunakan dalam pengukuran kadar air sebanyak 5 gram dengan minimal 2x ulangan. Benih kenanga dipotong menjadi bagian yang lebih kecil dengan menggunakan gunting kuku (destruktif) untuk mempercepat pengeringan. Benih kemudian dimasukkan dalam cawan krusibel dan diletakkan dalam oven. Periode pengeringan dimulai pada saat oven menunjukkan suhu $105^{\circ} \mathrm{C}$. Apabila pengeringan telah selesai, benih beserta cawan krusibel dimasukkan ke dalam desikator selama 30 menit untuk pendinginan. Setelah itu, benih beserta cawannya ditimbang. Kadar air dapat ditentukan dengan rumus sebagai berikut:

$$
\begin{aligned}
\text { Kadar Air (\%) } & =\frac{\text { susut berat }}{\text { berat awal }} \times 100 \% \\
& =\frac{M 2-M 3}{M 2-M 1} \times 100 \%
\end{aligned}
$$

Keterangan:

$$
\begin{aligned}
\text { M1 = } & \text { berat dalam gram dari wadah dan } \\
& \text { tutupnya } \\
\text { M2 = } & \text { berat dalam gram dari wadah, tutup dan } \\
& \text { isinya sebelum pengeringan } \\
\text { M3 = } & \begin{array}{l}
\text { berat dalam gram dari wadah, tutup dan } \\
\text { isinya sesudah pengeringan }
\end{array}
\end{aligned}
$$

Penetapan kadar air benih kenanga dilakukan sebanyak 6 kali ulangan. Sebanyak 3 ulangan untuk buah kenanga yang baru diunduh dari pohon dan 3 ulangan untuk buah yang jatuh karena masak fisiologis. Masing-masing ulangan dikerjakan secara duplo.

\section{Analisis Data}

Data yang diperoleh dari hasil pengamatan dianilisis secara deskriptif dan kuantitatif. Analisis kuantitatif untuk mengetahui hubungan antara ukuran buah dan jumlah benih dilakukan dengan uji korelasi. Pengolahan data dilakukan dengan menggunakan software MINITAB versi 16.

\section{HASIL DAN PEMBAHASAN}

\section{Hasil}

\section{Morfologi buah kenanga}

Buah kenanga memiliki bentuk bulat telur (Gambar 1a), ukuran panjang 7.40-27.5 mm, lebar 0.43$16.63 \mathrm{~mm}$ dan berat 0.36-2.88 gram. Buah yang belum masak berwarna hijau, sedangkan buah yang sudah 
masak fisiologis berwarna hijau tua sampai ungu kehitaman. Dalam satu buah kenanga terdapat 1-12 butir benih (Gambar 1b). Benih kenanga yang sudah diekstraksi (Gambar 1c) berwarna cokelat kehitaman dan memiliki struktur kulit benih yang keras. Benih kenanga yang berkecambah (Gambar 1d) memiliki radikula (calon akar) dan hipokotil berwarna merah keunguan. Benih kenanga memiliki tipe perkecambahan epigeal karena pada saat proses perkecambahan berlangsung kotiledon terangkat ke atas permukaan media.

Ukuran buah dapat menentukan jumlah benih dalam suatu buah. Hasil analisis korelasi menunjukkan adanya korelasi pada semua peubah pengamatan (Tabel 1). Panjang buah dan lebar buah memiliki nilai $r$ tertinggi dengan tingkat korelasi yang kuat. Panjang buah dan berat buah memiliki tingkat korelasi yang sedang terhadap jumlah benih dalam buah, sedangkan lebar buah memiliki tingkat korelasi yang lemah terhadap jumlah benih dalam buah. Hal ini menunjukkan bahwa semakin besar ukuran buah kenanga, maka semakin banyak jumlah benih yang terkandung dalam satu buah kenanga.

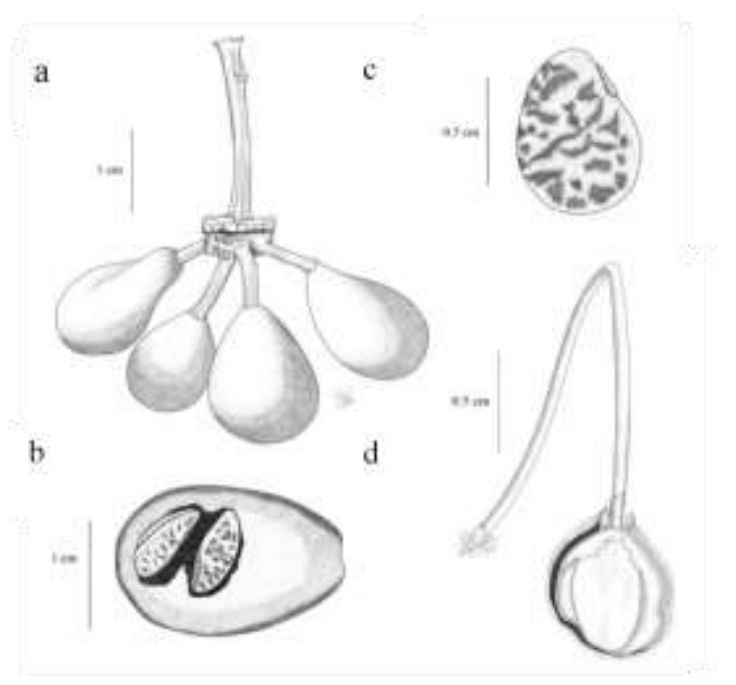

Gambar 1 Morfologi buah kenanga: a. buah kenanga bergerombol, b. posisi benih dalam buah kenanga, c. benih kenanga yang sudah diekstraksi, d. benih kenanga yang berkecambah

Tabel 1 Korelasi antara ukuran buah dan jumlah benih dalam satu buah kenanga

\begin{tabular}{lcl}
\hline Peubah pengamatan & $\mathrm{r}$ & $\begin{array}{c}\text { Tingkat } \\
\text { korelasi } \\
\text { (Chahyadi } \\
\text { et al. 2016) }\end{array}$ \\
\hline $\begin{array}{l}\text { Lebar buah x panjang buah } \\
\text { Panjang buah x jumlah } \\
\text { benih dalam buah }\end{array}$ & 0.72 & kuat \\
$\begin{array}{l}\text { Lebar buah x jumlah benih } \\
\text { dalam buah }\end{array}$ & 0.39 & sedang \\
$\begin{array}{l}\text { Berat buah x jumlah benih } \\
\text { dalam buah }\end{array}$ & 0.42 & lemah \\
\hline $\mathrm{r}=$ nilai korelasi & & sedang \\
\hline
\end{tabular}

2. Panjang buah

$\mathrm{mm}$

\begin{tabular}{|c|c|c|c|c|}
\hline No & Peubah & Satuan & $\begin{array}{l}\text { Hasil } \\
\text { penelitian }\end{array}$ & Literatur \\
\hline 1. & Warna buah & - & $\begin{array}{l}\text { hijau tua } \\
\text { sampai } \\
\text { ungu } \\
\text { kehitaman }\end{array}$ & $\begin{array}{l}\text { hijau tua } \\
\text { hingga } \\
\text { kehitaman } \\
\text { (Orwa et } \\
\text { al. 2009) }\end{array}$ \\
\hline 2. & Panjang buah & $\mathrm{mm}$ & $7.40-27.5$ & $\begin{array}{l}15-25 \\
\text { (Orwa et } \\
\text { al. 2009) }\end{array}$ \\
\hline 3. & $\begin{array}{l}\text { Jumlah benih } \\
\text { dalam buah }\end{array}$ & butir & $1-12$ & $\begin{array}{l}\text { 6-12 } \\
\text { (Manner } \\
\text { dan } \\
\text { Elevitch } \\
2006 \text { ) }\end{array}$ \\
\hline 4. & $\begin{array}{l}\text { Tipe } \\
\text { perkecambahan } \\
\text { benih }\end{array}$ & - & epigeal & $\begin{array}{l}\text { Epigeal } \\
\text { (Handayani } \\
2008 \text { ) }\end{array}$ \\
\hline
\end{tabular}

\begin{tabular}{|c|c|c|c|c|}
\hline No & Peubah & Satuan & $\begin{array}{l}\text { Hasil } \\
\text { penelitian }\end{array}$ & Literatur \\
\hline 1. & Warna buah & - & $\begin{array}{l}\text { hijau tua } \\
\text { sampai } \\
\text { ungu } \\
\text { kehitaman }\end{array}$ & $\begin{array}{l}\text { hijau tua } \\
\text { hingga } \\
\text { kehitaman } \\
\text { (Orwa } \text { et } \\
\text { al. 2009) }\end{array}$ \\
\hline 2. & Panjang buah & $\mathrm{mm}$ & $7.40-27.5$ & $\begin{array}{l}15-25 \\
\text { (Orwa et } \\
\text { al. 2009) }\end{array}$ \\
\hline 3. & $\begin{array}{l}\text { Jumlah benih } \\
\text { dalam buah }\end{array}$ & butir & $1-12$ & $\begin{array}{l}\text { 6-12 } \\
\text { (Manner } \\
\text { dan } \\
\text { Elevitch } \\
\text { 2006) }\end{array}$ \\
\hline 4. & $\begin{array}{l}\text { Tipe } \\
\text { perkecambahan } \\
\text { benih }\end{array}$ & - & epigeal & $\begin{array}{l}\text { Epigeal } \\
\text { (Handayani } \\
\text { 2008) }\end{array}$ \\
\hline
\end{tabular}

Perh

Penentuan berat 1000 butir benih kenanga ini sudah sesuai dengan Peraturan Direktur Jenderal Rehabilitasi Lahan dan Perhutanan Sosial Nomor: P.06/V-SET/2009. Berdasarkan peraturan ini dalam menentukan berat 1000 butir benih, nilai CV (koefisien harus di bawah 4.0, sedangkan dalam penelitian ini nilai $\mathrm{CV}$ yang diperoleh yaitu 1.34. Berat 1000 butir benih kenanga adalah 62.60 gram dan dapat diubah ke dalam jumlah benih per $\mathrm{kg}$ yaitu \pm 16000 butir dalam $1 \mathrm{~kg}$ benih kenanga.

Buah kenanga yang baru diunduh memiliki kadar air benih yang lebih tinggi dibandingkan dengan buah yang jatuh karena masak fisiologis. Kadar air benih dari buah kenanga yang baru diunduh berkisar antara 51.20$59.20 \%$, sedangkan kadar air benih dari buah kenanga yang jatuh karena masak fisiologis berkisar antara 34.57-37.82\% (Tabel 2).

\section{Pembahasan}

Tabel 3 menunjukkan bahwa terdapat kesamaan antara hasil pengamatan dengan literatur pada peubah warna buah dan tipe perkecambahan. Warna buah kenanga forma genuina sama dengan literatur yaitu hijau gelap hingga kehitaman (Orwa et al. 2009).

Tabel 2 Rekapitulasi data penetapan kadar air benih kenanga

\begin{tabular}{lcc}
\hline Kondisi buah & $\begin{array}{c}\text { Ulangan } \\
\text { ke- }\end{array}$ & $\begin{array}{c}\text { Kadar air benih } \\
(\%)^{*}\end{array}$ \\
\hline $\begin{array}{l}\text { Buah kenanga yang } \\
\text { baru diunduh dari }\end{array}$ & 1 & 58.80 \\
pohon & 2 & 56.00 \\
& 3 & 53.06 \\
Buah yang jatuh karena & 1 & 34.87 \\
masak fisiologis & 2 & 35.44 \\
& 3 & 37.72 \\
\hline
\end{tabular}
duplo.

Tabel 3 Perbandingan hasil pengamatan dan literatur 
Terangkatnya kotiledon ke atas permukaan media semai menunjukkan benih kenanga memiliki tipe perkecambahan epigeal (Handayani 2008).

Namun, hasil pengamatan pada peubah panjang buah dan jumlah benih dalam buah berbeda dengan literatur. Kisaran panjang buah hasil pengamatan lebih besar dibandingkan dengan literatur. Menurut Wietzke et al. (2018), pertumbuhan dan pematangan buah secara signifikan dipengaruhi oleh proses penyerbukan. Adanya buah yang berukuran lebih panjang maupun lebih pendek diduga karena kondisi iklim dan tempat tumbuh yang berbeda. Menurut Rodrigues et al. (2018), kondisi iklim suatu daerah mempengaruhi perkembangan serbuk sari. Durasi cuaca dengan musim hujan yang lebih panjang dapat mendukung kinerja serbuk sari. Produksi buah di musim hujan biasanya memiliki karakteristik fisik yang lebih besar. Kisaran jumlah benih dalam buah pada hasil pengamatan juga lebih besar dibandingkan dengan literatur (Tabel 3). Menurut Manner dan Elevitch (2006), dalam buah kenanga forma genuina terdapat 6-12 benih yang berwarna cokelat pucat dan berbentuk oval pipih. Adanya buah kenanga yang memiliki ukuran lebih kecil yang ditemukan dalam penelitian ini menyebabkan jumlah benih dalam buah juga lebih sedikit dibandingkan dengan hasil penelitian Manner dan Elevitch (2006).

Data pengukuran berat 1000 benih kenanga menunjukkan bahwa dalam $1 \mathrm{~kg}$ terdapat \pm 16000 butir, sehingga dapat diperkirakan berapa $\mathrm{kg}$ benih kenanga yang dibutuhkan saat kegiatan penanaman di lapangan. Informasi berat benih digunakan untuk menentukan jumlah benih yang diperlukan dalam persemaian sehingga memenuhi target siap tanam (Suita dan Nurhasybi 2012). Selain itu, data berat 1000 benih kenanga dapat digunakan untuk memperkirakan jumlah benih dalam kegiatan penyimpanan.

Buah kenanga memiliki ukuran yang proporsional karena adanya korelasi positif antara panjang, lebar, dan berat buah. Ukuran buah kenanga berkorelasi positif terhadap jumlah benih, sehingga semakin besar buah kenanga maka semakin banyak benih yang diproduksi. Hasil yang sama juga ditemukan pada sawo Rozika et al. (2013), dan srikaya (Aziz 2010). Diameter buah sawo berkorelasi positif terhadap bobot buah dan jumlah benih dalam buah. Tinggi rendahnya jumlah benih srikaya dipengaruhi oleh ukuran dan berat buah srikaya.

Menurut Parotta (2009), benih kenanga termasuk ke dalam benih ortodoks. Hasil penelitian menunjukkan kadar air benih kenanga dari buah yang masak fisiologis berkisar antara 34.57-37.82\%. Jika dilihat dari kadar airnya, benih kenanga tidak termasuk ke dalam golongan benih ortodoks. Menurut Mira et al. (2015), benih ortodoks memiliki kadar air benih segar sebelum masak fisiologis $15-31 \%$ dan kadar air benih saat masak fisiologis menurun hingga 6-10\%.

Benih ortodoks adalah benih yang masih dapat mempertahankan viabilitasnya meskipun kadar airnya diturunkan sampai dengan 10\% (Murrinie et al. 2017). Pada kasus kenanga hasil penelitian Athiyah (2008), penurunan kadar air benih kenanga sampai $14.4 \%$ menyebabkan viabilitasnya tinggal $20 \%$. Oleh karena itu, perlu dilakukan penelitian lebih lanjut untuk menetapkan benih kenanga termasuk dalam golongan ortodoks, rekalsitran atau semi rekalsitran. Menurut Walters (2015), ada beberapa variabel yang diperlukan untuk menetapkan suatu benih termasuk ke dalam golongan benih ortodoks, rekalsitran maupun semi rekalsitran. Variabel tersebut di antaranya adalah daya simpan benih, respon benih terhadap pengeringan, respon benih terhadap penurunan kadar air benih, peran triasilgliserol dalam benih terhadap suhu penyimpanan, dan pengaruh suhu penyimpanan terhadap viabilitas benih.

\section{SIMPULAN}

Buah kenanga berukuran panjang 7.40-27.5 mm, lebar $0.43-16.63 \mathrm{~mm}$ dan berat 0.36-2.88 gram. Terdapat korelasi antara ukuran buah dan jumlah benih dalam buah. Semakin besar ukuran buah maka semakin banyak jumlah benih dalam buah. Jumlah benih dalam satu buah kenanga adalah 1-12 butir.

Jumlah benih dalam $1 \mathrm{~kg}$ benih kenanga \pm 16000 butir. Kadar air benih dari buah kenanga yang baru diunduh lebih tinggi (51.20-59.20\%) dibandingkan dengan buah kenanga yang jatuh karena masak fisiologis $(34.57-37.82 \%)$.

\section{DAFTAR PUSTAKA}

Athiyah Z. 2008. Studi dormansi, kadar air kritikal, dan peningkatan kecepatan perkecambahan benih kenanga (Cananga odorata Lam. Hook.F \& Thoms.) [skripsi]. Bogor(ID): Institut Pertanian Bogor.

Aziz Z. 2010. Korelasi antar sifat-sifat buah pada tanaman srikaya (Annona squamosa L.) di daerah Sukolilo, Pati, Jawa Tengah [skripsi]. Surakarta (ID): Universitas Sebelas Maret.

Handayani T. 2008. Studi perilaku perkecambahan biji dan morfologi pertumbuhan semai kenanga (Cananga odorata Lam. Hook.F \& Thoms). Buletin Kebun Raya Indonesia 11(1):23-29.

Manner HI, Elevitch CR. 2006. Species Profiles for Pasific Island Agoforestry. Holualoa (US): Permanent Agiculture Resources (PAR).

Mira S, Estrelles E, Gonzalez ME. 2015. Effect of water content and temperature on seed longevity of seven brassicaceae species after 5 years of storage. Plant Biology 17(1):153-62.

Murrinie ED, Yudono P, Purwantoro A, Sulistyaningsih E. 2017. Di dalam: Putra AE, Kusumadewi S, Permata PA, Santoso B, Kabib M, editor. Seminar Nasional Teknologi dan Informatika (Buku 1); 2017 Juli 25; Kudus, Indonesia. Kudus (ID): Universitas Muria Kudus. hlm 509-516.

Orwa C, Mutua A, Kindt R, Jamnadass R, Anthony S. 2009. Cananga odorata. Agoforestry Database 4:1-5.

Parrotta JA. 2009. Cananga odorata (Lam) Hook.f. \& Thoms., 1855. Enzyklopadie der Holzgewachse $54: 1-8$ 
Peraturan Direktur Jenderal Rehabilitasi Lahan dan Perhutanan Sosial Nomor: P.06/V-SET/2009 tentang Petunjuk Teknis Pengujian Mutu FisikFisiologi Benih.

Propantoko H. 2018. Teknik silvikultur kenanga jawa (Cananga odorata forma macrophylla) di Blitar Jawa Timur [tesis]. Bogor (ID): Institut Pertanian Bogor.

Rodrigues BRA, Nitsche S, Mercadante MO, Pereira MCT, Ribeiro LM. 2018. Climatic seasonality influences the develompment of pollen grains and fruiting in Annona squamosa. Environmental and Experimental Botany $150 ; 240$ 148.doi:10.1016/j.envexpbot.2018.03.025.

Rozika, Murti RH, Purwanti S. 2013. Eksplorasi dan karakterisasi sawo (Manilkara zapota (L.) van Royen) di Daerah Istimewa Yogyakarta. Vegetalika 2(4):101-114.

Sudrajat DJ, Nurhasybi, Bramasto Y. 2015. Standar Pengujian dan Mutu Benih Tanaman Hutan. Bogor (ID): Forda Press.
Suita E, Nurhasybi. 2012. Pengujian Viabilitas Benih Weru (Albizia procera Benth). Bogor (ID): Balai Penelitian Teknologi Perbenihan Tanaman Hutan.

Sutopo L. 2004. Teknologi Benih. Jakarta (ID): PT Raja Gafindo Persada.

Walters C. 2015. Orthodoxy, recalcitrance and inbetween: describing variation in seed storage characteristics using threshold responses to water loss. Planta 242(2):397-406.

Wietzke A, Westphal C, Gras P, Kraft M, Pfohl K, Karlovsky P, Pawelzik E, Tscharntke T, Smit I. 2018. Insect pollination as a key factor for stawberry physiology and marketable fruit quality. Agriculture, Ecosystem and Environment 258:197204.doi:10.1016/j.agee.2018.01.036.

Zhang N, Zhang L, Feng L, Yao L. 2016. The anxiolytic effect of essential oil of Cananga odorata exposure on mice and determination of its major active constituents. Phytomedicine 23:1727-1734. 